\author{
섬유질 배합사료 원료로서 맥주박, 비지박 및 볏짚이 한우 거세우의 사양성적, \\ 혈액성상 및 도체특성에 미치는 영향 \\ 장선식 ${ }^{1} *$ · 권혁진 ${ }^{2} \cdot$ 이상민 ${ }^{1} \cdot$ 조영무 $^{1} \cdot$ 정기용 $^{1} \cdot$ 최낙진 $^{3} \cdot$ 이성실 ${ }^{4}$ \\ ${ }^{1}$ 농촌진흥청 국립축산과학원, ${ }^{2}$ 거제축협, ${ }^{3}$ 전북대학교 동물소재공학과, ${ }^{4}$ 경상대학교 응용생명과학부
}

\title{
Effects of Brewers Grain, Soybean Curd and Rice Straw as an Ingredient of TMR on Growth Performance, Serum Parameters and Carcass Characteristics of Hanwoo Steers
}

Sun Sik Chang ${ }^{1}$, Hyuk Jin Kwon ${ }^{2}$, Sang Min Lee ${ }^{1}$, Young Moo Cho ${ }^{1}$, Ki Yong Chung ${ }^{1}$, Nag Jin Choi ${ }^{3}$ and Sung Sill Lee ${ }^{4}$ ${ }^{1}$ National Institute of Animal Science, RDA, Pyeongchang, 232-950, Korea, ${ }^{2}$ Geoje Nonghyup Co. LTD., Geoje, 656-304, Korea, ${ }^{3}$ Department of Animal Science, Chonbuk National University, Jeonju 561-756, Korea, ${ }^{4}$ Division of Applied Life Science, Graduate School Gyeongsang National University, Jinju, 660-701, Korea

\begin{abstract}
This study was conducted to investigate the dietary effect of total mixed rations (TMR) containing brewers grain, soybean curd and rice straw, respectively, on growth performance and carcass characteristics of Hanwoo steers. Twenty four Hanwoo steers (average body weight $168 \mathrm{~kg}$ ) in 6 months age were randomly allocated to 4 experimental groups, which contained 6 animals per group during 22-months feeding trial. The treatment was composed of the group fed concentrate and rice straw separately(T1), the group fed TMR containing brewers grain(T2), the group fed TMR containing soybean curd(T3) and the group fed TMR containing rice straw (T4). Body weight (BW) was not different among treatment groups during the growing and middle fattening period. However, it was significantly greater in T4 group than in T2 group on the final $\mathrm{BW}(\mathrm{p}<0.05)$. Average daily gain was significantly greater in TMR groups compared to T1 group on the growing and late fattening $(\mathrm{p}<0.05)$. However, it was not different in total average. Dry matter intake tended to be increased in TMR groups. The feed conversion ratio was significantly lower in $\mathrm{T} 4$ group compare to $\mathrm{T} 2$ group $(\mathrm{p}<0.05)$. According to the yield traits, carcass weight of $\mathrm{T} 1, \mathrm{~T} 2, \mathrm{~T} 3$ and $\mathrm{T} 4$ were $389.0,368.4,387.5$ and $384.3 \mathrm{~kg}$, respectively. The back fat thickness, rib-eye area, and yield index were not different among the groups. Meat color, fat color, texture and maturity were not significantly different among groups. However, marbling score and appearance rate of meat quality grade of over $1^{+}$were greater in T2 and T3 groups compare to other groups. Therefore, these results indicated that TMR with brewers grain and soybean curd may be ameliorated the growth performance and carcass characteristics of Hanwoo steers.
\end{abstract}

(Key words : Total mixed ration, Hanwoo steers, Growth performance, Carcass characteristics)

서 론

우리나라 한우산업은 다국적 FTA 협상에 따른 소고기의 수입 증가, 원료사료 가격인상 등의 외부요인과 구제역 발생 및 사육두 수 증가에 따른 한우 가격 저하 등의 내부요인으로 인해 한우 사육 농가는 갈수록 위축 되고 있다. 한우농가의 어려움을 극복하기 위 해서는 생산비의 $70 \%$ 이상을 차지하는 사료비 (Sung, 2001)를 절 감하고 생산성을 높이는 방법이 우선되어야 할 것이다. 현재 우리 나라 가축에 이용되는 원료사료의 대부분은 수입에 의존하고 있어
전체 사료자급율은 약 $17 \%$ 수준이다. 최근 생산비를 절감하고 사 료 자급율 향상을 위해 농산부산물 (볏짚, 버섯폐배지, 녹차 부산물 등), 식품 가공부산물 (비지박, 맥주박 등) 및 야초류 (억새, 갈대 등) 등을 대체사료로 이용하고자 연구되어 왔다.

대체사료로 이용되고 있는 주요 부산물 중 비지박과 맥주박은 원 료 수급이 원활하고, 조단백질 및 $\mathrm{TDN}$ 이 높아 영양학적 가치가 우수하여 사료 가치가 매우 높은 부산물로 알려져 있다 (Sung, 2001, Shin 등, 2008). 하지만 맥주박과 비지박은 수분함량이 높 고, 저장성이 떨어져 부패하기 쉬워 가축의 기호성이 떨어진다

* Corresponding author: Sun Sik Chang, National Institute of Animal Science, RDA., Pyeongchang, 232-950, Korea. Tel: 033-330-0609, Fax: 033-330-0660, E-mail: Jangsc@korea.kr 
(Shin 등, 2008). 쌀을 주식으로 하는 우리나라에서 볏짚은 반추가 축의 주 조사료원으로 이용되고 있지만 리그닌 함량이 높아 영양소 소화율이 낮은 단점을 가지고 있다(Jackson, 1977).

섬유질배합사료(Total Mixed Ration)는 이러한 영양학적 가치 또는 기호성이 낮은 부산물을 효과적으로 이용할 수 있어 (Kim 등, 2003 사료비를 절감할 수 있고, 반추가축의 선택채식을 방지하여 영양학적 균형을 유도하며 반추위 $\mathrm{pH}$ 항상성을 유지하여 사료섭취 량을 증가시키고, 대사성 질병을 감소(Harrison 등, 1989; Kellems 등, 1991; Nocek 등, 1986)하여 생산성을 향상시킬 수 있다. 또한 가축관리에 대한 노동력 절감 및 자가배합에 의한 사료 생산비의 절감 등의 경제적 효과도 우수하다(Howard 등, 1968).

따라서 본 연구는 우리나라 주요 부산물인 맥주박, 비지박 및 볏 짚을 이용한 섬유질배합사료의 급여가 한우 거세우의 발육, 혈액성 상 및 도체특성에 미치는 영향을 구명하고자 수행하였다.

\section{재료 및 방법}

\section{1. 공시동물 및 시험설계}

본 연구는 생후 약 6 개월령 한우 거세우 24 두(평균체중 168 $\mathrm{kg}$ )를 공시하여, 국립축산과학원 한우시험장 (강원도, 대관령면)에 서 22개월간 사양시험을 수행하였고, 시험구 배치는 배합사료와 볏 짚 분리급여구 $(\mathrm{T} 1)$, 맥주박 첨가 섬유질배합사료 급여구 (T2), 비 지박 첨가 섬유질배합사료 급여구 (T3) 및 볏짚 첨가 섬유질배합사 료 급여구(T4)로 총 4처리, 처리당 6반복으로 완전임의 배치하여 수행하였다.

\section{2. 시험사료 및 사양관리}

각 처리구별로 시험에 이용한 사료는 시판되는 거세우 비육용 배 합사료와 강원도 지역에서 생산된 볏짚을 이용하였고, 섬유질배합 사료는 각 성장단계별 영양소 요구량을 고려한 배합비 (Table 1)에 따라 주문 생산하여 이용하였다. 시험사료의 일반성분 함량은 각각 의 시료 $(2.0 \mathrm{~kg})$ 를 수집하여 $\mathrm{AOAC}(1990)$ 방법에 준하여 분석하 여 Table 2에 나타내었다. 시험축은 콘크리트 재질 바닥의 톱밥 우사에서 군집사육 형태로 성장단계별로 Table 3에 따라 사양관리 되었다. 배합사료는 1 일 급여량을 2회 $(08: 00,16: 00)$ 균등분배 하 였고, 섬유질 배합사료와 볏짚은 자유채식토록 하였다. 물과 무기 물 (Super Licks, England)은 항시 섭취할 수 있도록 하였다.

Table 1. Fomula of diets used in this experiment (DM basis, \%)

\begin{tabular}{|c|c|c|c|c|c|c|c|c|c|c|}
\hline \multirow{2}{*}{ Item } & \multicolumn{3}{|c|}{ Growing } & \multicolumn{3}{|c|}{ Early fattening } & \multicolumn{3}{|c|}{ Mid fattening } & \multirow{2}{*}{$\begin{array}{c}\text { late fattening } \\
\mathrm{T} 2 \sim \mathrm{T} 4\end{array}$} \\
\hline & $\mathrm{T} 2^{1)}$ & $\mathrm{T}^{2)}$ & $\mathrm{T} 4^{3)}$ & $\mathrm{T} 2$ & $\mathrm{~T} 3$ & $\mathrm{~T} 4$ & $\mathrm{~T} 2$ & $\mathrm{~T} 3$ & $\mathrm{~T} 4$ & \\
\hline Corn gluten feed & 2.12 & 2.13 & 4.08 & 5.69 & 6.06 & 8.25 & 1.58 & - & - & - \\
\hline Molasses & 2.64 & 2.65 & 5.09 & 4.84 & 4.66 & 3.24 & 5.14 & 4.67 & 4.29 & 7.49 \\
\hline Soybean meal & 0.36 & 0.35 & 0.73 & - & - & - & - & - & 0.26 & 0.13 \\
\hline Soybean hull & 3.33 & 3.34 & 6.42 & 8.61 & 7.95 & 3.01 & 9.64 & 8.76 & 9.64 & 0.93 \\
\hline Vitamin & - & - & - & - & - & - & 0.06 & 0.06 & 0.06 & 0.09 \\
\hline Yeast & - & - & - & - & - & - & 0.06 & 0.06 & 0.06 & 0.09 \\
\hline Cottonseed meal & 0.19 & 0.18 & 0.35 & 0.24 & 0.42 & 1.57 & 23.05 & 18.64 & 22.78 & 30.94 \\
\hline Crushing wheat & 1.80 & 1.80 & 3.47 & 26.98 & 25.87 & 16.66 & 3.22 & 2.36 & 1.46 & 13.31 \\
\hline Beet pulp & 28.84 & 21.90 & 12.50 & 4.20 & 3.93 & 17.13 & 0.93 & 0.86 & 0.82 & 1.31 \\
\hline Limestone & 0.45 & 0.45 & 0.87 & 0.90 & 0.93 & 0.95 & 0.19 & 0.17 & 0.19 & 0.28 \\
\hline Salt & 0.14 & 0.14 & 0.27 & 0.18 & 0.19 & 0.19 & 2.57 & 2.33 & 6.24 & 1.87 \\
\hline Wheat bran & 14.33 & 14.35 & 27.65 & 4.96 & 6.63 & 18.04 & - & - & 0.24 & - \\
\hline Corn germ meal & 5.37 & 5.39 & 10.38 & - & - & - & 17.49 & 20.16 & 17.83 & 36.62 \\
\hline Corn powder & 4.50 & 4.51 & 8.66 & 6.46 & 6.44 & 6.01 & 0.33 & 0.30 & 0.33 & 0.58 \\
\hline $\mathrm{CaHPO}_{4}$ & 0.20 & 0.20 & 0.39 & 0.33 & 0.32 & 0.30 & 14.54 & 13.16 & 13.15 & - \\
\hline Tall fescue & 9.37 & 8.45 & - & 10.01 & 15.43 & - & 16.62 & 21.69 & 22.48 & 5.88 \\
\hline Rice straw & 7.63 & 8.83 & 19.16 & 14.55 & 9.30 & 24.64 & 0.18 & 0.17 & 0.18 & 0.47 \\
\hline Brewers grain & 18.74 & - & - & 12.06 & - & - & 4.40 & - & - & - \\
\hline Soybean curd residue & - & 25.35 & - & - & 11.87 & - & - & 6.62 & - & - \\
\hline
\end{tabular}

1) T2 : TMR containing brewers grain.

${ }^{2)} \mathrm{T} 3$ : TMR containing soybean curd.

${ }^{3)} \mathrm{T} 4$ : TMR containing rice straw. 
Table 2. Chemical composition of diets used in this experiment (DM basis, \%)

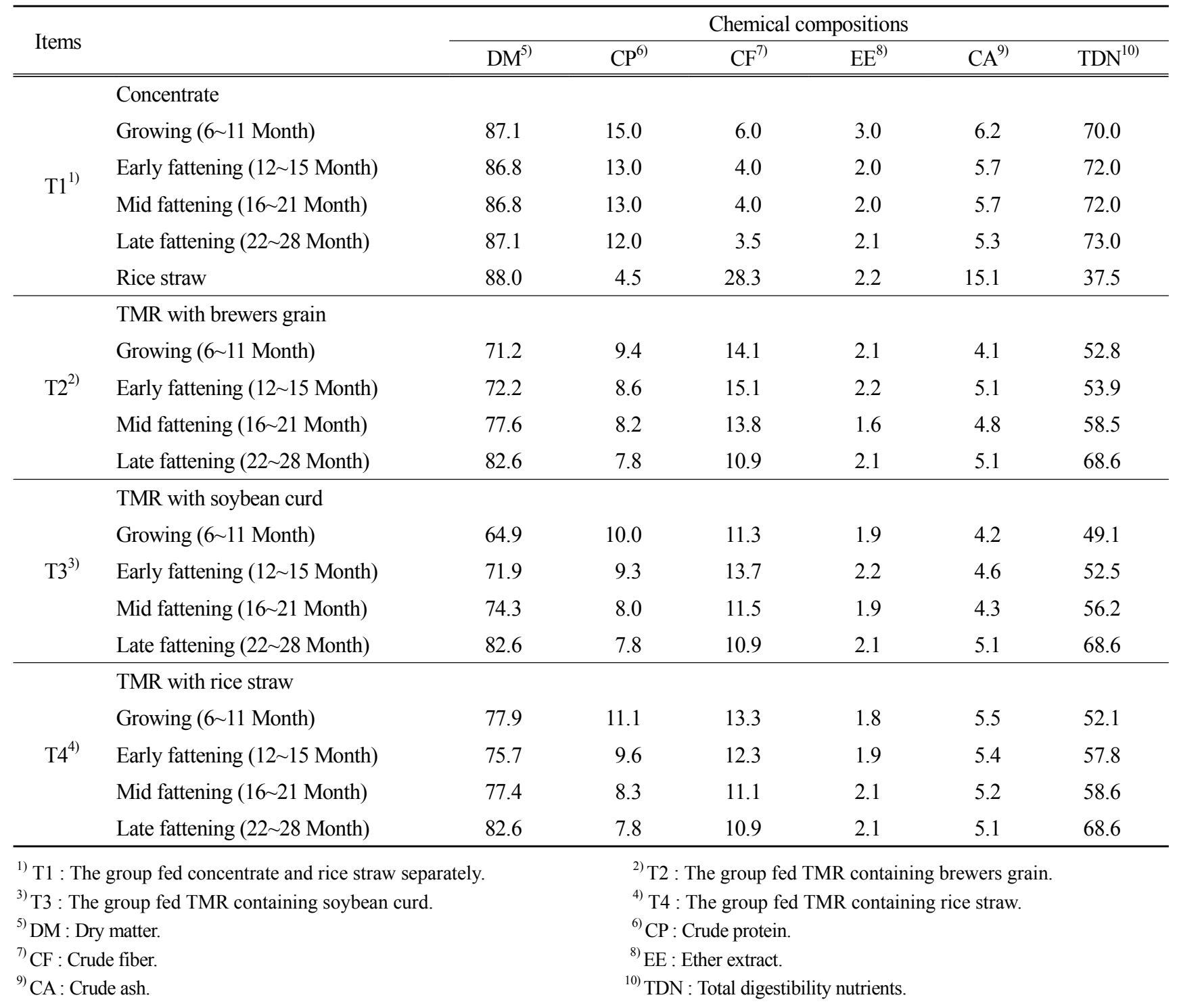

\section{3. 조사항목}

\section{(1) 체중 측정}

체중조사는 시험 개시일부터 종료 시까지 시험축사 내에 설치 된 우형기(CAS Korea, Newton HT-501A)로 매월 오전 사료급여 전에 조사하였다. 일당증체량은 이전 체중에서 금회 측정된 체중의 차를 사육 일수로 나누어 구하였다. 사료섭취량은 오전 사료 급여 전 사료 급이기 내의 잔량을 조사한 후 전날 급여량에서 공제한 값 을 섭취량으로 계산하였다.

(2) 혈액성분 분석

시험축의 혈액은 시험 개시일부터 종료 시까지 성장단계별로 체 중조사와 함께 공시축의 경정맥에서 Serum vacutainer (BD
Vacutainer serum REF 367820 , USA)에 약 $10 \mathrm{ml}$ 혈액을 채취 하여 $4^{\circ} \mathrm{C}$ 에서 원심분리기 (한일, KRI supra $21 \mathrm{~K}$, Korea)로 $3,000 \mathrm{rpm}$ 에서 15 분간 원심분리하여 $-70^{\circ} \mathrm{C}$ Ultra-low temperature upright freezers (Thermo scientitic, USA)에서 분석 전까지 냉동 보관 하였다. 혈청 내 glucose, BUN, cholesterol, creatinine, total protein 농도는 생화학 자동분석기 (CIBA-EXPRESS PLUS) 를 이용하여 측정하였다.

\section{(3) 도체조사}

도체조사는 사양시험이 종료된 공시축을 농협중앙회 부천축산물 공판장에서 도축한 후, $0^{\circ} \mathrm{C}$ 에서 18 24시간 동안 도체를 현수시킨 후 육량판정요인 (도체중, 등지방두께, 배최장근단면적)과 육질판정 요인 (근내지방도, 육색, 지방색, 조직감 및 성숙도)을 소도체등급판 
Table 3. Feeding management of experimental animals (Dry matter basis)

\begin{tabular}{|c|c|c|c|c|}
\hline \multirow[b]{2}{*}{ Item } & \multicolumn{4}{|c|}{ Feeding periods (Month of age) } \\
\hline & $\begin{array}{c}\text { Growing } \\
(6 \sim 11)\end{array}$ & $\begin{array}{c}\text { Early fattening } \\
(12 \sim 15)\end{array}$ & $\begin{array}{l}\text { Mid fattening } \\
\quad(16 \sim 21)\end{array}$ & $\begin{array}{c}\text { Late fattening } \\
\text { (22 Finish) }\end{array}$ \\
\hline \multicolumn{5}{|l|}{$\mathrm{T}^{\mathrm{T}}{ }^{1)}$} \\
\hline Concentrate (BW, \%) & $1.5 \sim 1.6$ & $1.6 \sim 1.7$ & $1.7 \sim 1.8$ & 1.8 Ad libitum \\
\hline Rice straw & \multicolumn{4}{|c|}{ Ad libitum } \\
\hline $\mathrm{T} 2^{2)}, \mathrm{T}^{3)}, \mathrm{T} 4^{4)}$ & \multicolumn{4}{|c|}{ Ad libitum } \\
\hline
\end{tabular}

\footnotetext{
${ }^{1)} \mathrm{T} 1$ : The group fed concentrate and rice straw separately. $\quad{ }^{2)} \mathrm{T} 2:$ The group fed TMR containing brewers grain.

${ }^{3)} \mathrm{T} 3$ : The group fed TMR containing soybean curd. $\quad{ }^{4)} \mathrm{T} 4:$ The group fed TMR containing rice straw.
}

정기준에 의거하여 축산물등급 판정사가 평가하였다.

\section{4. 통계처리}

본 시험에서 얻어진 모든 성적들은 SAS package (Statistical Analysis System software version 9.2, 2011)를 이용하여 분산분 석 및 처리구간 유의성 $(\mathrm{p}<0.05)$ 을 검증하였다.

\section{결과 및 고찰}

\section{1. 체중 및 영양소섭취량}

한우 거세우의 사료종류별 (T1: 배합사료와 볏짚 분리급여구, $\mathrm{T} 2$ :
맥주박 첨가 섬유질배합사료 급여구, $\mathrm{T} 3$ : 비지박 첨가 섬유질배합 사료 급여구 및 $\mathrm{T} 4$ : 볏짚 첨가 섬유질배합사료 급여구) 체중 및 일 당증체량은 Table 4와 같다. 각 처리구별 개시, 육성기 및 비육 전-중기의 체중은 처리구들간 차이가 없었지만, 종료시 체중은 처 리구별로 각각 $644.0,624.0,653.8$ 및 $680.3 \mathrm{~kg}$ 으로 $\mathrm{T} 4$ 처리구가 $\mathrm{T} 2$ 처리구에 비해 유의적으로 높았다 $(\mathrm{p}<0.05)$. 일당증체량에 있어 서는 $\mathrm{T} 1$ 처리구가 육성기에서 가장 낮았고 $(\mathrm{p}<0.05)$, 비육중기에서 는 가장 높았다 $(\mathrm{p}<0.05)$. 비육후기에서는 $\mathrm{T} 4$ 처리구가 가장 높았 지만 $(\mathrm{p}<0.05)$, 전체 평균에서는 처리구들간 유의적인 차이는 없었 다. 영양소섭취량(단백질, TDN 및 건물섭취량)은 군집사육 방법으 로 인해 처리구간 통계적 유의차를 제시하지 못하였지만, 건물섭취 량은 시험개시 후 종료시까지 섬유질배합사료 처리구 $(\mathrm{T} 2, \mathrm{~T} 3$ 및 T4)가 분리급여구에 비해 많은 것으로 조사되었다. 단백질 섭취량

Table 4. The changes of body weight during growing and fattening phases of Hanwoo steers fed experimental diets

\begin{tabular}{|c|c|c|c|c|}
\hline Items & $\mathrm{T} 1^{1)}$ & $\mathrm{T} 2^{2)}$ & $\mathrm{T}^{3)}$ & $\mathrm{T} 4^{4)}$ \\
\hline \multicolumn{5}{|l|}{ Body weight (kg) } \\
\hline Initial (6 month of age) & $169.0 \pm 12.3$ & $157.2 \pm 6.5$ & $168.3 \pm 11.5$ & $170.7 \pm 12.0$ \\
\hline 11 month of age & $274.3 \pm 14.1$ & $285.2 \pm 9.4$ & $301.7 \pm 9.7$ & $302.2 \pm 8.6$ \\
\hline 15 month of age & $393.7 \pm 15.1$ & $400.0 \pm 13.4$ & $416.7 \pm 9.2$ & $418.8 \pm 5.4$ \\
\hline 21 month of age & $496.1 \pm 16.9$ & $469.1 \pm 13.6$ & $486.8 \pm 11.5$ & $492.8 \pm 5.8$ \\
\hline Final (28 month of age) & $644.0 \pm 15.2^{\mathrm{ab}}$ & $624.0 \pm 14.4^{\mathrm{b}}$ & $653.8 \pm 12.6^{\mathrm{ab}}$ & $680.3 \pm 12.1^{\mathrm{a}}$ \\
\hline \multicolumn{5}{|l|}{ Average daily gain (kg) } \\
\hline Growing (6 11 Month of age) & $0.65 \pm 0.03^{\mathrm{b}}$ & $0.80 \pm 0.03^{\mathrm{a}}$ & $0.83 \pm 0.02^{\mathrm{a}}$ & $0.82 \pm 0.05^{\mathrm{a}}$ \\
\hline Early Fattening (12 15 Month of age) & $0.79 \pm 0.01$ & $0.76 \pm 0.04$ & $0.76 \pm 0.04$ & $0.77 \pm 0.06$ \\
\hline Mid Fattening (16 21 Month of age) & $0.87 \pm 0.04^{\mathrm{a}}$ & $0.59 \pm 0.03^{b}$ & $0.60 \pm 0.06^{\mathrm{b}}$ & $0.63 \pm 0.02^{b}$ \\
\hline Late Fattening (22 28 Month of age) & $0.84 \pm 0.04^{\mathrm{b}}$ & $0.87 \pm 0.04^{\mathrm{b}}$ & $0.94 \pm 0.04^{\mathrm{ab}}$ & $1.06 \pm 0.07^{\mathrm{a}}$ \\
\hline Overall & $0.78 \pm 0.02$ & $0.77 \pm 0.02$ & $0.80 \pm 0.03$ & $0.84 \pm 0.04$ \\
\hline
\end{tabular}

$\begin{array}{ll}{ }^{1)} \mathrm{T} 1 \text { : The group fed concentrate and rice straw separately. } & { }^{2)} \mathrm{T} 2: \text { The group fed TMR containing brewers grain. }\end{array}$

${ }^{3)} \mathrm{T} 3$ : The group fed TMR containing soybean curd.

4) $\mathrm{T} 4$ : The group fed TMR containing rice straw.

Means \pm standard error

${ }^{a, b}$ Means with different superscripts in the same row differ significantly $(p<0.05)$. 
에 있어서 육성기 및 비육전기에서는 섬유질배합사료 급여구가 높 은 경향을 보였고, 비육 중·후기 및 전체평균에서는 분리급여구가 높은 경향을 보였다. $\mathrm{TDN}$ 에 있어서는 전기간에서 섬유질배합사료 급여구가 분리급여구에 비해 높은 것으로 나타났다. 사료요구율은 육성기에서는 $\mathrm{T} 3$ 처리구가 가장 낮았고 $(\mathrm{p}<0.05)$, 비육 전·중기에 서는 분리급여구가 가장 낮게 나타났다 $(\mathrm{p}<0.05)$. 또한, 비육후기 및 전기간 평균에서는 $\mathrm{T} 4$ 처리구가 가장 낮았다 $(\mathrm{p}<0.05)$.

Cho 등 (2008)은 섬유질배합사료를 급여한 거세한우의 생후 28 개월 종료체중은 $605 \sim 619 \mathrm{~kg}$, 일당증체량은 전기간 평균 0.68 $0.70 \mathrm{~kg} /$ 일로 본 연구 보다 다소 낮은 결과를 나타내었는데, 연구 간 사료 내 영양소 수준 및 급여량에 따른 결과로 판단된다. 본 연 구의 결과에서 $\mathrm{T} 2$ 처리구를 제외한 섬유질배합사료 처리구가 종료 시 체중 및 일당증체량이 분리급여구 보다 우수한 것으로 나타났는 데, Kang 등 (2005)과 Cho 등 (2008)의 연구에서도 분리급여구에 비해 섬유질배합사료 급여구가 높은 성장률을 보였다. 분리급여구 에 비해 섬유질배합사료 급여구의 섭취량이 대체적으로 높았는데, 이전의 연구에서도 분리급여구의 선택채식에 비해 섬유질배합사료 는 반추위 안정성으로 사료섭취량을 증가시킨 것으로 판단된다 (Harrison 등, 1989; Kellems 등, 1991; Nocek 등, 2007). 또한 Cho 등 (2008)은 한우 거세우의 분리급여 및 섬유질 배합사료의 급여시 사료요구율이 9.29 11.63 kg으로 본 연구의 결과와 차이가 없었다. 또한 Choi 등 (2006)은 거세흑염소에 맥주박 급여 시 분리 급여구에 비해 섭취량 및 사료요구율이 증가한다고 하였는데, 본 연구에서도 T2 처리구가 높은 경향을 나타내었다. 하지만, Hathch 등 (1972)은 비육우에 맥주박과 알파파를 급여했을 때 일당증체량 및 사료요구율에 있어 차이가 없는 만큼 사료가치가 우수하다고 하 였고, McCarthy 등 (1990)은 대두박을 급여한 면양이 맥주박에 비 해 사료요구율이 낮았다고 보고하였다. Woo 등 (2011)의 연구에서 도 분리급여구에 비해 비지박을 첨가한 섬유질발효사료의 급여가 육성기 한우 암소의 성장을 향상시킨다고 하였다.

육성기 분리급여구의 증체가 낮은 것은 육성기 건물, 조단백질 및 TDN의 섭취량이 섬유질 배합사료의 영양소섭취량에 비해 낮은 결과로 판단되고, 비육중기에서 높은 것은 조단백질 및 $\mathrm{TDN}$ 의 섭 취가 향상된 결과에 따른 것으로 생각된다. 전기간 평균에서 분리 급여구가 조단백질 섭취량이 가장 높았고, TDN 섭취량은 가장 낮 은 결과를 나타내었는데, 사료요구율에서 조단백질 섭취량은 높았 지만, $\mathrm{TDN}$ 섭취량이 가장 낮은 분리급여구가 $\mathrm{T} 2, \mathrm{~T} 3$ 처리구에 비해 높게 나타났다. 하지만, 군집사양관리로 인해 개체별 성적과 처리구간 통계처리를 할 수 없어 정확한 원인을 알 수 없지만, 객 관적으로 볼 때 사료급여 효과라기 보다 개체유전적 요인에 의한 결과로 판단된다.

\section{2. 혈액성상}

한우 거세우의 성장단계별 사료종류에 따른 혈청 대사물질의 농 도 변화는 Table 6에 나타내었다. 한우 거세우의 성장단계별 혈청
내 creatinine과 total protein 농도는 처리구간 유의적인 차이가 없었다. Cholesterol 및 $\mathrm{BUN}$ 농도는 비육기에서 분리급여구(T1) 가 섬유질배합사료 급여구 $(\mathrm{T} 2, \mathrm{~T} 3$ 및 $\mathrm{T} 4)$ 에 비해 유의적으로 높 았다 $(\mathrm{p}<0.05)$. glucose의 농도는 비육중기에서 $\mathrm{T} 1$ 처리구가 $\mathrm{T} 3$ 처리구 보다 유의적으로 높았다 $(\mathrm{p}<0.05)$.

혈액 내 대사물질은 영양소 이용과 대사를 측정할 수 있는 지표 이다(Choi 등, 2009; Vernon, 1992). 혈액 내 BUN의 농도는 체 내 질소축적량(Enright 등, 1990; Choi 등, 2009)으로 배합사료 분리급여구가 섬유질 배합사료에 비해 높은 경향을 나타내었다. 본 연구의 결과에서 나타난 BUN 농도는 일반적 수준범위인 10 20 $\mathrm{mg} / \mathrm{dl}$ 으로(Choi등, 2005 Kwon 등, 2005), 개체 및 사료종류에 의한 차이로 판단된다(Choi 등, 2009; Cho 등, 2008). Cholesterol 의 농도는 에너지 섭취량에 정의 관계를 가지는데 (Arave 등, 1975), 비육기의 배합사료 섭취량이 섬유질배합사료에 비해 높은 것에 따른 결과라 생각된다. 또한 Glucose는 반추동물의 지방합성 의 중요 요소로(Choi 등, 2009; Vernon, 1992), 비육기 glucose 농도가 섬유질 배합사료 급여구가 분리급여구에 비해 높은 결과가 근내지방도 및 육질등급출현율에 영향을 준 것이라 생각되며, 차후 추가적인 연구가 필요할 것으로 판단된다.

\section{3. 도체 특성}

한우 거세우의 사료종류별 도체특성을 알아보기 위하여 각 처리 구별 6두씩 시험 도축 후 도체성적의 결과는 Table 7에 나타내었 다. 육량특성 중 도체중은 처리구별로 각각 $389.0,368.4,387.5$ 및 $384.5 \mathrm{~kg}$ 으로 처리구간 유의적인 차이는 없었다 $(\mathrm{p}>0.05)$. 또한, 등지방두께는 $\mathrm{T} 2$ 가 등심단면적은 $\mathrm{T} 1$ 처리구가 높은 경향을 보였 지만, 처리구간 유의적 차이는 없었다. 육량지수는 각 처리구별로 각각 $65.3,63.6,66.1$ 및 67.8 로 유의적인 차이는 없었고, 육량지 수의 결과에서 알 수 있듯이 육량등급 출현율 $(\%)$ 에서 육량 $\mathrm{A}, \mathrm{B}$ 출현율에서 $\mathrm{T} 3, \mathrm{~T} 4$ 처리구가 조금 나은 성적을 나타내었다. 육질 특성 중 육색, 지방색, 조직감 및 성숙도는 처리구간 차이는 없었 다. 육질등급 판정의 주요 요인인 근내지방도는 처리구별로 각각 $5.2,6.2,6.7$ 및 5.7로 $\mathrm{T} 3$ 처리구가 높은 경향을 보였지만, 통계 적인 유의차이는 나타나지 않았다. 육질등급출현율 $\left(1^{++}: 1^{+}: 1: 2, \%\right)$ 은 각각 0:50:33:17, 0:50:20:0, 17:66:17:0 및 0:66:17:17로 육질 $1^{+}$등급이상 출현율은 $\mathrm{T} 3$ 처리구가 $83 \%$ 로 향상된 성적을 보였다. Cho 등 (2008)은 한우 거세우의 육량특성 (도체중, 등심단면적, 등지방두께 및 육량지수)에 있어서 분리급여구와 섬유질배합사료간 차이가 나타나지 않았다고 하였고, $\mathrm{Kim}$ 등 (2003)도 한우 거세우 의 육량특성 (도체중, 등지방두께 및 등심단면적)에 있어 유의적 차 이가 나타나지 않아 본 연구의 결과와 일치하였다. 또한 $\mathrm{Kim}$ 등 (2003)은 육질특성 중 근내지방도에 있어서는 섬유질배합사료 급 여구가(4.6) 분리급여구(4.0)가 비해 높은 경향을 나타내었고, Cho 등 (2008)의 연구에서도 분리급여구 3.4 에 비해 습식 섬유질 배합사료 급여구 5.0 으로 높게 나타났는데, 본 연구에서도 분리급 
Table 5. The changes of feed intake and feed conversion ratio during growing and fattening phases of Hanwoo steers fed experimental diets

\begin{tabular}{|c|c|c|c|c|}
\hline Item & $\mathrm{T} 1^{1)}$ & $\mathrm{T}^{2)}$ & $\mathrm{T}^{3)}$ & $\mathrm{T} 4^{4)}$ \\
\hline \multicolumn{5}{|l|}{ Feed intake Growing (6 11 Month of age) } \\
\hline Concentrate/TMR & 3.91 & 7.81 & 7.84 & 7.77 \\
\hline Rice straw & 1.66 & - & - & - \\
\hline $\mathrm{DMI}^{5)}$ & 4.86 & 5.56 & 5.09 & 6.06 \\
\hline $\mathrm{CP}$ & 0.67 & 0.73 & 0.78 & 0.86 \\
\hline TDN & 3.36 & 4.12 & 3.86 & 4.04 \\
\hline \multicolumn{5}{|l|}{ Early-fattening (12 15 Month of age) } \\
\hline Concentrate/TMR & 5.85 & 11.81 & 11.77 & 11.87 \\
\hline Rice straw & 2.84 & - & - & - \\
\hline DMI & 7.58 & 8.53 & 8.46 & 8.99 \\
\hline $\mathrm{CP}$ & 0.93 & 1.01 & 1.10 & 1.14 \\
\hline TDN & 5.2 & 6.4 & 6.2 & 6.9 \\
\hline \multicolumn{5}{|l|}{ Mid-fattening (16 21 Month of age) } \\
\hline Concentrate/TMR & 8.16 & 11.64 & 11.74 & 11.40 \\
\hline Rice straw & 1.92 & - & - & - \\
\hline DMI & 8.78 & 9.04 & 8.72 & 8.82 \\
\hline $\mathrm{CP}$ & 1.15 & 0.96 & 0.94 & 0.95 \\
\hline TDN & 6.60 & 6.81 & 6.60 & 6.68 \\
\hline \multicolumn{5}{|l|}{ Late-fattening (22 28 Month of age) } \\
\hline Concentrate/TMR & 9.31 & 12.37 & 12.08 & 11.74 \\
\hline Rice straw & 0.90 & - & - & - \\
\hline DMI & 8.89 & 10.22 & 9.98 & 9.70 \\
\hline $\mathrm{CP}$ & 1.06 & 0.96 & 0.94 & 0.91 \\
\hline TDN & 7.13 & 8.49 & 8.29 & 8.05 \\
\hline \multicolumn{5}{|l|}{ Overall period } \\
\hline Concentrate/TMR & 7.23 & 11.21 & 11.14 & 10.95 \\
\hline Rice straw & 1.76 & - & - & - \\
\hline DMI & 7.83 & 8.67 & 8.40 & 8.64 \\
\hline $\mathrm{CP}$ & 1.01 & 0.93 & 0.95 & 0.96 \\
\hline TDN & 5.87 & 6.75 & 6.54 & 6.68 \\
\hline \multicolumn{5}{|l|}{ Feed conversion ratio (feed/gain kg) } \\
\hline Growing (6 11 Month of age) & $7.51 \pm 0.35^{\mathrm{a}}$ & $7.03 \pm 0.26^{\mathrm{ab}}$ & $6.16 \pm 0.14^{\mathrm{b}}$ & $7.54 \pm 0.43^{\mathrm{a}}$ \\
\hline Early Fattening (12 15 Month of age) & $9.67 \pm 0.16^{\mathrm{b}}$ & $11.43 \pm 0.63^{\mathrm{ab}}$ & $11.34 \pm 0.61^{\mathrm{ab}}$ & $12.09 \pm 0.98^{\mathrm{a}}$ \\
\hline Mid Fattening (16 21 Month of age) & $10.22 \pm 0.46^{\mathrm{b}}$ & $15.68 \pm 1.07^{\mathrm{a}}$ & $15.43 \pm 1.65^{\mathrm{a}}$ & $14.14 \pm 0.45^{\mathrm{a}}$ \\
\hline Late Fattening (22 28 Month of age) & $10.75 \pm 0.52^{\mathrm{ab}}$ & $11.79 \pm 0.57^{\mathrm{a}}$ & $10.68 \pm 0.50^{\mathrm{ab}}$ & $9.42 \pm 0.76^{\mathrm{b}}$ \\
\hline Overall period & $10.50 \pm 0.23^{\mathrm{ab}}$ & $11.32 \pm 0.27^{\mathrm{a}}$ & $10.58 \pm 0.34^{\mathrm{ab}}$ & $10.41 \pm 0.04^{\mathrm{a}}$ \\
\hline
\end{tabular}


Table 6. The changes of serum parameters during growing and fattening phases of Hanwoo steers fed experimental diets

\begin{tabular}{|c|c|c|c|c|c|}
\hline Item & & 11 Month of age & 15 Month of age & 21 Month of age & Finish \\
\hline \multirow{4}{*}{ Cholesterol (mg/100ml) } & $\mathrm{T} 1^{1)}$ & $148.0 \pm 30.0$ & $189.3 \pm 34.8^{\mathrm{a}}$ & $129.2 \pm 14.2^{\mathrm{a}}$ & $160.5 \pm 20.5^{\mathrm{a}}$ \\
\hline & $\mathrm{T} 2^{2)}$ & $146.8 \pm 46.8$ & $127.3 \pm 15.6^{\mathrm{b}}$ & $101.3 \pm 22.4^{\mathrm{b}}$ & $104.6 \pm 28.5^{\mathrm{b}}$ \\
\hline & $\mathrm{T}^{3)}$ & $156.4 \pm 16.3$ & $149.0 \pm 21.1^{\mathrm{b}}$ & $104.8 \pm 22.6^{\mathrm{b}}$ & $82.3 \pm 11.1^{\mathrm{bc}}$ \\
\hline & $\mathrm{T} 4^{4)}$ & $156.5 \pm 36.8$ & $136.0 \pm 21.6^{\mathrm{b}}$ & $89.5 \pm 9.6^{b}$ & $100.5 \pm 27.0^{\mathrm{bc}}$ \\
\hline \multirow{4}{*}{ Creatinine (mg/100ml) } & $\mathrm{T} 1$ & $1.00 \pm 0.12$ & $1.27 \pm 0.14$ & $0.98 \pm 0.04$ & $1.23 \pm 0.18$ \\
\hline & $\mathrm{T} 2$ & $0.83 \pm 0.08$ & $1.12 \pm 0.08$ & $0.88 \pm 0.08$ & $1.16 \pm 0.11$ \\
\hline & $\mathrm{T} 3$ & $0.86 \pm 0.09$ & $1.32 \pm 0.08$ & $0.92 \pm 0.08$ & $1.23 \pm 0.23$ \\
\hline & $\mathrm{T} 4$ & $0.88 \pm 0.12$ & $1.25 \pm 0.15$ & $0.88 \pm 0.10$ & $1.27 \pm 0.24$ \\
\hline \multirow{4}{*}{ Glucose (mg/100ml) } & $\mathrm{T} 1$ & $65.00 \pm 3.81$ & $60.17 \pm 12.35$ & $76.16 \pm 7.73^{b}$ & $59.33 \pm 8.26$ \\
\hline & $\mathrm{T} 2$ & $63.27 \pm 5.88$ & $61.83 \pm 9.15$ & $78.00 \pm 7.87^{\mathrm{ab}}$ & $66.04 \pm 7.44$ \\
\hline & $\mathrm{T} 3$ & $63.83 \pm 4.12$ & $65.50 \pm 8.53$ & $86.67 \pm 2.66^{\mathrm{a}}$ & $60.17 \pm 3.76$ \\
\hline & $\mathrm{T} 4$ & $69.83 \pm 9.87$ & $70.33 \pm 7.69$ & $85.00 \pm 8.46^{\mathrm{ab}}$ & $69.50 \pm 5.75$ \\
\hline \multirow{4}{*}{ Total protein $(\mathrm{mg} / 100 \mathrm{ml})$} & $\mathrm{T} 1$ & $5.62 \pm 0.19$ & $6.18 \pm 0.24$ & $5.96 \pm 0.28$ & $5.75 \pm 0.57$ \\
\hline & $\mathrm{T} 2$ & $5.86 \pm 0.27$ & $6.30 \pm 0.22$ & $6.02 \pm 0.22$ & $6.17 \pm 0.17$ \\
\hline & $\mathrm{T} 3$ & $5.70 \pm 0.15$ & $6.02 \pm 0.13$ & $5.70 \pm 0.17$ & $5.40 \pm 0.50$ \\
\hline & $\mathrm{T} 4$ & $5.72 \pm 0.28$ & $5.97 \pm 0.31$ & $5.72 \pm 0.33$ & $6.02 \pm 0.64$ \\
\hline \multirow{4}{*}{ BUN (mg/100ml) } & $\mathrm{T} 1$ & $11.34 \pm 2.04$ & $13.53 \pm 1.71^{\mathrm{a}}$ & $8.62 \pm 1.65^{\mathrm{a}}$ & $14.58 \pm 2.48^{\mathrm{a}}$ \\
\hline & $\mathrm{T} 2$ & $9.62 \pm 0.79$ & $8.62 \pm 1.39^{b}$ & $5.68 \pm 1.21^{\mathrm{bc}}$ & $7.60 \pm 2.04^{\mathrm{ab}}$ \\
\hline & $\mathrm{T} 3$ & $11.98 \pm 2.24$ & $8.58 \pm 1.96^{\mathrm{b}}$ & $4.72 \pm 0.79^{c}$ & $8.63 \pm 1.42^{\mathrm{a}}$ \\
\hline & $\mathrm{T} 4$ & $11.76 \pm 2.40$ & $9.55 \pm 1.41^{\mathrm{b}}$ & $7.20 \pm 1.83^{\mathrm{ab}}$ & $7.25 \pm 1.90^{\mathrm{b}}$ \\
\hline
\end{tabular}

${ }^{1)} \mathrm{T} 1$ : The group fed concentrate and rice straw separately. ${ }^{2)} \mathrm{T} 2:$ The group fed TMR containing brewers grain.

${ }^{3)}$ T3 : The group fed TMR containing soybean curd. ${ }^{4)}$ T4 : The group fed TMR containing rice straw.

Means \pm standard error $\quad{ }_{a, b, c}$ Means with different superscripts in the same row differ significantly $(\mathrm{p}<0.05)$.

Table 7. Carcass traits of Hanwoo steers fed experimental diets

\begin{tabular}{|c|c|c|c|c|}
\hline \multirow{2}{*}{ Items } & \multicolumn{4}{|c|}{ Treatments } \\
\hline & $\mathrm{T} 1^{1)}$ & $\mathrm{T} 2^{2)}$ & $\mathrm{T}^{3)}$ & $\mathrm{T}^{4)}$ \\
\hline \multicolumn{5}{|l|}{ Yield traits } \\
\hline Carcass weight (kg) & $389.0 \pm 11.1$ & $368.4 \pm 11.9$ & $387.5 \pm 5.8$ & $384.3 \pm 11.1$ \\
\hline Back fat thickness (mm) & $13.5 \pm 2.0$ & $15.2 \pm 2.5$ & $11.3 \pm 1.0$ & $11.7 \pm 1.0$ \\
\hline Rib-eye area $\left(\mathrm{cm}^{2}\right)$ & $85.8 \pm 1.8$ & $81.0 \pm 5.1$ & $84.8 \pm 3.4$ & $80.8 \pm 2.0$ \\
\hline Yield index & $65.3 \pm 2.1$ & $63.6 \pm 1.8$ & $66.1 \pm 0.6$ & $67.8 \pm 1.0$ \\
\hline Yield grade (A:B:C, \%) & $17: 66: 17$ & $0: 80: 20$ & $17: 83: 0$ & 17:83:0 \\
\hline \multicolumn{5}{|l|}{ Quality traits } \\
\hline Marbling score ${ }^{5)}$ & $5.2 \pm 0.6$ & $6.2 \pm 0.4$ & $6.7 \pm 0.7$ & $5.7 \pm 0.6$ \\
\hline Meat color ${ }^{6)}$ & $4.8 \pm 0.2$ & $4.6 \pm 0.2$ & $4.5 \pm 0.2$ & $5.0 \pm 0.0$ \\
\hline Fat color ${ }^{7)}$ & $3.0 \pm 0.0$ & $3.0 \pm 0.0$ & $3.0 \pm 0.0$ & $3.0 \pm 0.0$ \\
\hline Texture $^{8)}$ & $1.3 \pm 0.5$ & $1.0 \pm 0.0$ & $1.0 \pm 0.0$ & $1.17 \pm 0.2$ \\
\hline Maturity $^{9)}$ & $2.0 \pm 0.0$ & $2.0 \pm 0.0$ & $2.3 \pm 0.2$ & $2.0 \pm 0.0$ \\
\hline Quality grade $\left(1^{+}: 1^{+}: 1: 2, \%\right)$ & $0: 50: 33: 17$ & $0: 80: 20: 0$ & $17: 66: 17: 0$ & $0: 66: 17: 17$ \\
\hline
\end{tabular}

1) T1 : The group fed concentrate and rice straw separately. ${ }_{4}^{2)} \mathrm{T} 2$ : The group fed TMR containing brewers grain.

${ }^{3)}$ T3 : The group fed TMR containing soybean curd. $\quad{ }^{4)} \mathrm{T} 4$ : The group fed TMR containing rice straw.

5) Marbling score : 1=devoid, 9=abundant.

7) Fat color : 1=creamy white, $7=$ yellowish

6) Meat color : 1=bright red, $7=$ dark red

9) Maturity : 1=young, 9=old

8) Texture : $1=$ soft, $3=$ firm

Means \pm standard error. 
여구의 근내지방도 5.2에 비해 섬유질배합사료 급여구가 5.7 6.7의 범위로 높은 경향을 나타내었다. Park 등 (2003)과 Cho 등 (2008) 은 섬유질배합사료가 배합사료와 볏짚을 분리급여하는 것보다 영양 생리적 측면에서 우수하다고 보고하였고, 맥주박 및 볏짚과 같은 조사료 부산물에 비해 단백질사료원인 비지박 첨가 섬유질배합사료 (Kwak and Yoon, 2003)가 한우 거세우의 도체특성에 보다 긍정 적인 효과를 나타낸 것으로 판단된다.

$$
\text { 요 약 }
$$

본 연구는 맥주박, 비지박 및 볏짚을 각각 이용하여 배합한 $\mathrm{TMR}$ 을 한우 거세우에게 급여하였을 때 사양성적, 혈액성상 및 도 체특성을 구명하고자 수행되었다. 시험구는 6개월령 한우 거세우 24 두 (평균체중 $168 \mathrm{~kg}$ )를 배합사료 볏짚 분리급여구 $(\mathrm{T} 1)$, 맥주박 첨가 $\mathrm{TMR}$ 급여구 $(\mathrm{T} 2)$, 비지박 첨가 $\mathrm{TMR}$ 급여구 $(\mathrm{T} 3)$ 및 볏짚 첨가 $\mathrm{TMR}$ 급여구 $(\mathrm{T} 4)$ 에 각각 6 두씩 완전임의 배치하여 총 22개 월간 사양시험을 실시하여 28 개월령에 도축하였다. 시험결과에서 체중은 육성기에서 비육전기까지 처리구들간 유의적인 차이는 없었 다. 하지만, 종료시 체중에서 $\mathrm{T} 4$ 처리구가 $\mathrm{T} 2$ 처리구에 비해 유의 적으로 높았다. 일당증체량은 육성기 및 비육중기에서 TMR 급여 구가 $\mathrm{T} 1$ 에 비해 유의적으로 높았지만 $(\mathrm{p}<0.05)$, 전체평균에서는 차 이가 없었다. 건물섭취량은 $\mathrm{TMR}$ 급여구 $(\mathrm{T} 2, \mathrm{~T} 3, \mathrm{~T} 4)$ 에서 높은 경향을 나타내었다. 사료요구율은 $\mathrm{T} 2$ 처리구에 비해 $\mathrm{T} 4$ 처리구가 유의적으로 낮았다 $(\mathrm{p}<0.05)$. 육량특성에서 도체중은 $\mathrm{T} 1, \mathrm{~T} 2, \mathrm{~T} 3$ 및 T4 처리구에서 각각 $389.0,368.4387 .5$ 및 $384.3 \mathrm{~kg}$ 이었다. 등지방두께, 등심단면적 및 육량지수는 처리구들간 유의적 차이는 없었다. 육질특성에서 육색, 지방색, 조직감 및 성숙도에서는 처리 구간 유의적인 차이가 있었으나, 근내지방도와 육질 $1^{+}$등급 이상 출현율에서는 $\mathrm{T} 2$ 와 $\mathrm{T} 3$ 처리구가 다른 처리구에 비해 높았다. 따라 서 본 연구의 결과 맥주박과 비지박을 이용한 TMR 사료는 한우 거세우의 발육 및 도체특성에 있어 적절한 것으로 나타났다. (주제어 : 섬유질배합사료, 한우거세우, 발육, 도체특성)

\section{인 용 문 헌}

A.O.A.C. 1990. Official method of analysis. 15th ed. Assoc. Offic. Chem., Arlington, VA, USA.

Arave, C. W., Miller, R. H. and Lamb, R. C. 1975. Genetic and environmental effects on serum cholesterol of dairy cattle of various ages. J. Dairy Sci. 58:3-11.

Cho, Y. M., Kwon, E. G., Chang, S. S., Kim, T, I., Park, B. K., Kang, S. W. and Paek, B. H. 2008. Effects of Total Mixed Rations on Growth Performance and Carcass Characteristics of Hanwoo Steers. J. Anim. Sci. \& Technol. (Kor.) 50:363-372.
Choi, C. W., Baek, K. H., Kim, S. J., Oh, Y. K., Hong, S. K., Kwon, E. K., Song, M. K. and Choi, C. B. 2009. Effects of polyclonal antibodies to abdominal and subcutaneous adipocytes on ruminal fermentation patterns and blood metabolites in korean native steers. J. Anim. Sci. \& Technol. 51:231-240.

Choi, S. H., Hwangbo, S., Kim, S. W., Sang, B. D., Kim, K. Y. and Jo, I. H. 2006. Effects of total mixed ration with wet brewer's grain on the performance and nutrient utilization in castrated Korean black goats. J. Korean Grassl. Sci. 26:199-206.

Enright, W. J., Quirke, J. F., Gluckman, P. D., Breier, B. H., Kennedy, L. G., Hart, I. C., Rochecoert, J. F. and Allen, P. 1990. Effects of long-time administration of pituitary-derived bovine growth hormone and estradiol on growth in steers. J. Anim. Sci. 68:2345-2356.

Harrison, J. H., Riley, R. E. and Long, K. A. 1989. Effect of type and amount of buffer addition to grass silage-based total mixed rations on milk production and composition. J. Dairy. Sci. 72:1824-1830.

Hathch, C. F., Perry, T. W., Mohler, M. T. and Beeson, W. M. 1972. Effects of corn distillers soluble and brewers dried grains with yeast in urea-containing rations on steer performance. J. Anim. Sci. 34:326-331.

Howard, W. T., Albright, J. L., Cunningham, M. D., Harrington, R. B. and Noller, C. J. 1968. Least cost complete ration for Dairy cows. J. Dairy Sci. 69:2755.

Jackson, M. G. 1977. The alkali treatment of straws. Anim. Feed Sci. Technol. 2:105.

Kang, S. W., Ki, K. S., Oh, Y. K., Kim, K. H. and Choi, C. W. 2005. Effects of Roughage Feeding Type during the Growing and Early-Fattening Periods on Growth Performance, Feed Efficiency and Carcass Characteristics in Holstein Steers. J. Anim. Sci. \& Technol. (Kor.) 47:769-782.

Kellems, R., Jones, O. R., Andrus, D. and Wallentine, M. V. 1991. Effect of moisture in total mixed rations on feed consumption and milk production and composition in Holstein cows. J. Dairy. Sci. 74:929-932.

Kim, K. H., Kim. K., Lee, S. C., Oh. Y. G., Chung, C. S. and Kim, K. J. 2003. Effects of Total Mixed Rations on Ruminal Characteristics, Digestibility and Beef Production of Hanwoo Steers. J. Anim. Sci. \& Technol. (Kor.) 45:387-396.

Kwak, W. S. and Yoon, J. S. 2003. On-site Output Survey and Feed Value Evaluation on Agroindustrial By-products. J. Anim. Sci. \& Technol. (Kor.) 45:251-264.

Kwon, E. G., Hong, S. K., Seong, H. H., Yun, S. G., Park, B. K., Cho, Y. M., Cho, W. M., Chang, S. S., Shin, K. J. and Paek, B. H. 2005. Effects of Ad libitum and restricted feeding 
concentrates on body weight gain, feed intake and blood metabolites of Hanwoo steers at various growth stages. J. Anim. Sci. \& Technol. (Kor.) 47:745-758.

McCarthy, F. D., Norton, S. A. and McClure, W. H. 1990. Utilization of an ensiled wet brewers' grains-corn mixture by growing lambs. Anim. Feed Sci. \& Tech. 28:29-38.

Nocek, J. E., Steele, R. E. and Braund, D. G. 1986. Performance of dairy cows fed forage and grain separately versus a total mixed ration. J. Dairy Sci. 69:2140-2147.

Park, B. K., Gil. M. J., Kim, J. B., Hong, B. J., Ra, C. S. and Shin, J. S. 2003. Effects of Fermented Feedstuff with Wet Brewer's Grain and Soybean on Fattening Performance and Carcass Grade in Hanwoo Steers. J. Anim. Sci. \& Technol. (Kor.) 45:397-408.

SAS. 2011. SAS/STAT Software for PC. Release 6.11, SAS Institute, Cary, NC, U.S.A.
Shin, J. S., Lin, G. Z. and Kim, B. W. 2008. The effect of alcohol fermented feedstuff made ofbyproducts on fermentation characteristics and dry matter disappearance in the rumen. J. Kor. Grassl. Forage Sci. 28:49-60.

Sung, K. I. 2001. Efficient use of the Agri-byproducts. pp 61-86. National Institute of Animal Science, RDA.

Vernon, R. G. 1992. Control of lipogenesis and lipolysis. In : The control of fat and lean deposition (Eds. Boorman, K. N., Buttery, P. J. and Lindsay, D. B.). Butterworth, Heinemann, Oxford.

Woo, J. S., Jang, S. S., Im, S. K., Lee, S. D., Lee, M. S., Park, J. Y. Hong, S. K. Lee, S. S. and Lee, S. M. 2011. Effects of Total Mixed Fermentations with Bean Curd Dregs on Growth Performance of Growing Hanwoo Heifers. J. Life Sci. 21:14601465.

(Received Aug. 4, 2012; Revised Feb. 20, 2013; Accepted Feb. 25, 2013) 